\section{THE INTERNATIONAL CONFERENCE ON SCIENTIFIC LITERATURE.}

THE official report of the proceedings of the second International Conference on Scientific Literature, recently held in the rooms of the Society of Antiquaries, the rooms of the Royal Society being under repair, is given below. The names of the delegates who attended the Conference have already been published in NATURE (p. 579).

\section{ACTA.}

Opening Meeting, Tuesday, October it.

(I) Prof. Darboux moved that Sir John E. Gorst be the President of the Conference. The vote having been unanimously accepted-

(2) Sir John Gorst took the chair and welcomed the delegates.

It was then resolved-

(3) That Prof. Armstrong be the Secretary for the English language.

That Prof. Korteweg be the Secretary for the German language.

That M. La Fontaine be the Secretary for the French language.

(4) That the Secretaries, with the help of shorthand reporters, be responsible for the procis verbal of the proceedings of the Conference in their respective languages.

(5) Prof. Foster read out the names of delegates appointed to attend the Conference, and gave an account of the correspondence relating to the non-representation of certain countries.

The following resolutions were then agreed to :-

(6) That the ordinary hours of meeting be II a.m. to I p.m., and 2.30 to 4.30 p.m.

(7) That each delegate shall have a vote in deciding all questions brought before the Conference.

(8) That English, French, and German be the official languages of the Conference, but that it shall be open for any delegate to address the Conference in any other language, provided that he supplies for the procès verbal of the Conference a written translation of his remarks into one or other of the official languages.

(9) Prof. Foster having formally presented the Report of the Committee of the Royal Society, copies of which were forwarded, in April last, to the several Governments represented at the Conference, the discussion of the recommendations was opened, and it was resolved-

(10) That the Conference confirms the principle that the Catalogue be published in the double form of cards and book.

(II) That Schedules of Classification shall be authorised for the several branches of science which it is decided to include in the Catalogue.

(I2) That geography be defined as limited to mathematical and physical geography, and that political and general geography be excluded.

(13) That anatomy be entered on the list as a separate subject.

(I4) That a separate schedule be provided for each of the following branches of science.

Mathematics.

Astronomy.

Meteorology.

Physics.

Crystallography.

Chemistry.

Mineralogy.

Geology (including Petrology).

Geography-Mathematical and Physical.

Palæontology.

Anatomy.

Zoology.

Botany.

Physiology (including Pharmacology and Experimental Pathology).

Bacteriology.

Psychology.

Anthropology.

(I5) That each of the sciences for which a separate schedule is provided shall be indicated by a symbol.

(I6) Prof. Foster announced the reception of a letter from the German Chargé d'Affaires to the President of the Royal Society, stating that Geiheimer Regierungs-Rath Professor Dr. Klein, of Goettingen, had been appointed German Delegate to the Conference.

The regulations to be observed in the preparation of cards or slips were then taken into consideration, and it was resolved-

(I7) That Italian should be added to the list of languages not requiring translation.

NO. I 5 I 3 , VOL. 58 ]
(18) That for each communication to be indexed at least one slip, to be called a Primary Slip, shall be prepared, on which shall be either printed or type-written or legibly handwritten in Roman script-

(i.) Title-entries. -The author's name and the full title of the communication, in the original language alone if the language be either English, French, German, Italian, or Latin.

In the case of other languages, the title shall be trans. lated into English or such other of the above five languages as may be determined by the Collecting Bureau concerned; but in such case the original title shall be added, either in the original script, or transliterated into Roman script.

The title shall be followed by every necessary reference, including the year of publication, and such other symbols as may be determined. In the case of a separately published book, the place and year of publication, and the number of pages, \&c., shall be given.

(ii.) Subject-entries, indicating as briefly as possible the principal subjects to which the communication refers. Every effort shall be made to restrict the number of these subject-entries.

Such subject-entries shall be given only in the original language of the communication if this be one of the five previously referred to, but in other cases in English or in such other language as has been used in translating the title.

[The Belgian delegates stated that they abstained from voting on the part of this resolution relating to subject-entries.]

\section{Second Meeting, Wednesday, October 12.}

(19) Prof. Korteweg having expressed the desire to be relieved of his office, it was resolved that Prof. Weiss be appointed Secretary for the German language.

The following resolutions were adopied :-

(20) That the registration symbols used in the Catalogue be based on a convenient combined system of letters, numbers, or other symbols, adapted in the case of each branch of science to its individual needs, and in accordance, as far as possible, with a general system of registration.

(2I) That the authoritative decision as to the Schedules be entrusted to an International Committee, to be hereafter nominated by this Conference.

(22) That the Conference is of opinion that the Delegates should be requested to take steps in their respective countries to organise local committees charged with the study of all ques. tions relating to the International Catalogue of Scientific Literature, and to report within six months to the International Committee.

(23) That the International Committee (Resolution 22) be instructed to frame a report, not later than July 3I, I899, which shall be issued by the Royal Society, and incorporated in the decisions of the Conference.

(24) That in all countries in which, or wherever, a Regional Bureau is established, as contemplated in the I6th Resolution of the International Conference of 1896 , the Regional Bureau shall be responsible for the preparation (in accordance with Reg. 7 of the Royal Society's Report) of the slips requisite for indexing. all the scientific literature of the region, whatever be the language in which that literature may appear.

That each Regional Bureau shall transmit such slips to the Central Bureau as rapidly and as frequently as may be found convenient.

That in the case of countries in which no Regional Bureau is established, the Central Bureau, failing other arrangements, shall, upon special mandate, endeavour to undertake the work of a Regional Bureau.

[The Belgian delegates stated that they abstained from voting. on this resolution.]

(25) That the following recommendations of the Royal Society relating to the preparation of the Book Catalogue be referred to the International Committee for their favourable consideration, viz.:-

"At determined regular intervals, not necessarily the same for all sciences, the Central Bureau shall compile from the slips and issue in a book form both an authors' and a subject index of the literature published within that period.

This Book Catalogue shall be obtainable in parts correspond- 
ing to the several sciences for which slips are provided, and in such divisions of parts as may be hereafter determined.

In compiling the authors' index, in each of the sciences, the authors' names shall be arranged in alphabetical order, and each name shall be followed by the title of the paper and the necessary reference, and any other such symbols as may be determined.

The Book Subject Catalogue shall be compiled from the slips, as follows :-

(i.) The subject entries shall be grouped in sections corresponding to the registration letters on the slips, i.e. to the several sciences.

(ii) In each science the several subject entries shall be arranged under headings corresponding to the registration numbers on the slips, the which headings and numbers shall be those contained in the authorised schedules of classification.

(iii.) The divisions indicated by registration numbers may be further subdivided by means of significant words or symbols.

(iv.) The nature of the suhject entry may vary. Thus, as suggested in the cases of Mathematics and Physiology, it may be the title only; whilst in other sciences a special entry, more or less different from the title, may be provided on each slip. In all cases, the number of subject entries to be copied from a slip shall be determined by the number of registration numbers on the slip.

(v.) The mode of arranging subject entries under a registration number, or under the subdivisions of a number afforded by significant words or symbols, may vary. They may either be arranged in the order of authors' names placed alphabetically, in which case the author's name shall precede the subject entry in the Book Catalogue, or they may be arranged either in an arbitrary order, or in some order suited to the particular series of entries.

When in preparing an issue of the Book Catalogue, it is found that a registration number has no entries collected under it, the number and corresponding heading may be omitted from that issue.

To each part of the Book Catalogue corresponding to an authorised schedule, there shall be appended an alphabetical index of the headings, and if expedient, also of the significant words appearing in that part, showing on which page of the part cach niay be found.

After the publication of the first issue of the Book Catalogue, the Director of the Central Bureau shall consult the Committees of Referees as to the desirability of making changes in the classification, and shall report thereon to the International Council, who shall have power to authorise such changes to be made as they may think expedient."

(26) That the following recommendations of the Royal Society providing for International Conventions in connection with the Catalogue be adopted:-

"Each region in which a Regional Bureau is established, charged with the duty of preparing and transmitting slips to the Central Bureau for the compilation of the Catalogue, shall be called a 'constituent region.'

In 1905 , in 1910 , and every tenth year afterwards, an Inter. national Convention shall be held in London (in July) to reconsider and, if necessary, revise the regulations for carrying out the work of the Catalogue authorised by the International Convention of 1898 .

Such an International Convention shall consist of delegates appointed by the respective Governments to represent the constituent regions, but no region shall be represented by more than three delegates.

The rules of procedure of each International Convention shall be the same as those of the International Convention of 1898

The decisions of an International Convention shall remain in force unitil the next Convention meets."

27. That the following recommendations of the Royal Society relating to the constitution of an International Council, which shall be the governing body of the Catalogue, be adopted :-

"Each Regional Bureau shall appoint one person to serve as a member of a body to be called The International Council.

The International Council shall, within the regulations laid down by the International Convention, be the Governing Body of the Catalogue.

The International Council shall appoint its own Chairman and Secretary.

No I 5 I 3 , VOL. 58 ]
It shall meet in London once in three years at least, and at such other times as the Chairman, with the concurrence of five other members, may specially appoint.

It shall, subject to the regulations laid down by the Convention, be the supreme authority for the consideration of and decision concerning all matters belonging to the Central Bureau.

It shall make a report of its doings, and submit a balance sheet, copies of which shall be distributed to the several Regional Bureaux, and published in some recognised periodical or periodicals, in each of the constituent regions."

(28) That the following recommendations of the Royal Society relating to International Committees of Referees be referred for consideration to the International Council when constituted :-

"The International Council shall appoint for each science in cluded in the Catalogue five persons skilled in that science, to form an International Committee of Referees, provided always that the Committees shall be as far as possible representative of the constituent regions. The members shall be appointed in such a way that one retires every year. Occasional vacancies shall be filled up by the Committee itself, subject to the approval of the Chairman of the International Council, and a member thus appointed shall hold office as long as the member whose place he fills would have held office.

It shall be the duty of the Director of the Central Bureau to consult the appropriate Committee or Committees. by correspondence or otherwise, on all questions of classification not provided for by the Catalogue Regulations; or, in cases of doubt, as to the meaning of those Regulations.

In any action touching classification the Director shall be guided by the written decision of a majority of the appropriate Committee, or by a minute if the Committee meets.

Provided always that when any addition to or change of the schedule of classification in any one branch may seem likely to affect the schedule of classification of some other branch or branches, the Committees concerned shall have been consulted; and provided also that in all cases of want of agreement within or between the Committees, or of other difficulty, the matter shall have been referred for decision to the International Council.

All business transacted by the Committees shall be reported by the Director to the International Council at their next ensuing meeting."

\section{Third Meating, Thursday, October i3.}

The following resolutions were adopted :-

(29) That the Committee contemplated in Resolution 2I be constituted as follows :-

Prof. Armstrong.

Prof. Descamps.

Prof. M. Foster.

Dr. S. P. Langley.

Prof. Poincaré.

Prof. Riicker.

Prof. Waldeyer.

Prof. Weiss.

That this Committee be at liberty, if any of those named are unable to serve, to appoint substitutes, and also to co-opt two new members.

(30) That the International Committee be termed the "P'ro. visional International Committee."

(3I) That the Provisional International Committee shall be governed by the decisions of the Conference, but shall have the power of introducing such modifications in detail as may appear necessary.

(32) Dr. Adler, referring to Resolution 20, said that he desired to place on record his view that the concluding words" and in accordance, as far as pussible, with a general system of registration"--the addition which he had agreed to as an amendment of his original Resolution, must not be regarded as modifying the first part of the Clause, or as in any way throwing open the whole question of notation and classification.

(33) Prof. Ruicker having made a statement as to the probable cost of the undertaking, aud the Delegates having stated what assistance in their opinion might be expected from their respective countries, it was resolved-

That the Delegates to this Conference be requested to obtain information, and to report at an early date to the "Provisional International Committee," as to what assistance, by subscription or otherwise, towards the support of the Central Bureau, may be expected from their respective countries.

(34) M. Mascart called attention to Resolution 22 as being, in his opinion, incorrect in English, the intention being that the 
local Committees therein referred to should report to the International Committee.

(35) The Royal Society was requested to undertake the editing, publication, and distribution of a verbatim report of the Proceedings of the Conference.

(36) It was resolved that the proce's verbal of the Conference be signed by the President and Secretaries.

(37) On the motion of Prof. Armstrong, the thanks of the Conference were accorded to the Society of Antiquaries for the use of their rooms.

(38) On the motion of Prof. Klein, a vote of thanks to Sir John Gorst for presiding over the Conference, and his conduct in the chair, was passed by acclamation.

(39) On the motion of M. Darboux, a vote of thanks was passed to the Royal Society for their work in preparation for the Conference and their cordial reception of the Delegates.

$$
\text { (Signed) }\left\{\begin{array}{l}
\text { John E. Gorst, President. } \\
\text { Henry E. Armstrong } \\
\text { H. Ia Fontaine } \\
\text { E. Weiss }
\end{array}\right\} \text { Secretaries. }
$$

\section{NOTES.}

THE British Institute of Preventive Medicine, which was founded with the view of establishing in this country a national home for bacteriological work in all its branches, has made considerable progress towards the achievement of this aim during the past few years. The bacteriological laboratories are now fully organised, the serum therapeutics laboratory is on a firm footing, whilst the applications of bacteriology to hygiene are finding full recognition. A further addition has just been made to the departments of the Institute in response to the growing demands of the times. A large laboratory at Chelsea has been assigned to investigation and instruction in technical bacteriology. In this laboratory the agriculturist, the chemist, the brewer, and others will find the instruction provided that they individually require for successfully em. ploying the living agents of fermentation. Investigations will also be undertaken, and it is hoped that the laboratory will become a centre of useful work, and promote the advancement of a line of research of the greatest importance to the industries of the country. We have had hitherto to rely upon the research work of foreign laboratories in this direction. The laboratory has been named the Hansen laboratory, in recognition of the pioneer work of the distinguished investigator, and will be under the superintendence of Dr. G. I Iarris Morris. The formal opening of the British Institute will take place early in the new year, when the public will have an opportunity of inspecting the provisions made for furthering the objects of the Institute. The occasion will also be marked by the issue of a fresh volume of Transactions of the Institute, the first number of which was recently reviewed in these columns.

A I.FTTER signed “D.Sc. (Lond.)," referring to a Science and Art Department's examination, appeared in NATURE of September 8 (p. 435), and in it the writer gave the following as an instance of anomalies which occur in examinations :- "A student sat for the examination in May last in the advanced stage of practical organic chemistry. He was required to answer two questions, and to analyse two substances (unknown), as well as to find the halogen element present in an organic solid, and to determine the melting point of this solid. The written questions were correctly answered, the analyses were correctly done, the halogen was correctly determined, and the melting point of the substance was less than I per cent. too low. The description of the practical work was also fairly well done; but this student is returned as having failed, notwithstanding that there are two classes of success, first and second class. It would be interesting to know, in the face of this, the standard the examiners require for a first class success." Particulars which NO. I 5 I 3 , VOL. 58 ] enabled the examiner to again look at the paper worked by the candidate referred to were afterwards furnished us by "D.Sc.," and the examiner now reports upon it as follows:- "The written questions were partly answered, and on this part of the examination the candidate would have been allowed to pass; but the analyses were both very badly done, and the answers quite wrong. For the detection of the halogen and for the melting point he received the full marks awarded to this part of the work." It will be seen from this that the suggestion of un. fair marking madie by our correspondent is entirely without foundation. With regard to the other point referred to in the letter, we are sorry to say that "D.Sc." would not furnish us with the name of the class in which he said that by the new rules the earnings this session will be reduced 75 per cent. We regret having unconsciously done an injustice to the Department of Science and Art by the publication of his letter.

THE following interesting announcement appears on a page in the catalogue of Messrs. Johnson, Matthey, and Co., Hatton Garden, London :- "In furtherance of scientific research, Professors and recognised scientific investigators will with pleasure be supplied with metals of the platinum group, in moderate quantities, and for periods to be arranged, free of charge, on condition that the precious metals are ultimately returned (in any form), and that the results of the investigations are fur. nished."

A PI.EA for a national Antarctic expedition is made by Sir Clements Markham in a pamphlet published by the Royal Geographical Society. As was pointed out last week, in referring to the special Antarctic number of the Scottish Geographical Magazine, the only hope of maintaining the credit of our country in the work of exploration lies in an appeal to the patriotic feelings of those who possess the power which wealth supplies of providing the funds. The Council of the Royal Geographical Society generously offers to head the list with a subscription of $5000 \%$. This example should be the means of showing that geographers are willing to help geographical discovery so far as their funds permit ; and it also expresses their views upon the necessity of Antarctic exploration in an unmistakable form. It is earnestly to be hoped that the desire to enable the nation to retain its position as the first in exploration and discovery will inspire our wealthy countrymen to provide an amount equal to at least ten such subscriptions as that of the Royal Geographical Society. If this sum is not forthcoming, the prestige and credit won by former explorations will have to be resigned, and other nations will take our place as leaders in the work of geographical discovery.

AN attendant at the Pathological Institute attached to the Vienna (ieneral IIospital, died on October 18 from bubonic plague. It is believed that the man became infected by handling cultures of the plague bacillus. His duties were to look after the animals kept for the bacteriological study of the plague, but how he became infected has not yet been discovered. There is no doubt that the case was one of plague, an examination of the sputum having revealed the presence of the plague bacillus. Since the assistant's death, Dr. Müller, who attended him, has also died from the plague, and a nurse infected by it is described as in a condition which leaves little hope of recovery.

THE Times correspondent at Copenhagen announces that an international monument in honour of the famous Danish physician, Dr. Hans Wilhelm Meyer, who died three years ago, was unveiled in that city on Tuesday. Dr. Meyer was the discoverer of what are called adenoid growths. He found that the space between the nose and the throat, which ordinarily is an open cavity, is in certain persons suffering from deafness more or less closed by a large, soft mass. It found that this mass in 